\title{
Perception Level of Voluntary Counselling/Testing and Knowledge/ Awareness of HIV/AIDS among Adult Population in Ugep Town of Cross- River State of Nigeria
}

\author{
Akpotuzor Josephine O*, Akpan Patience A and Akwiwu Euphoria C \\ Department of Medical Laboratory Science, University of Calabar, Calabar, Nigeria
}

\begin{abstract}
The Human Immune deficiency Virus (HIV) and Acquired Immune Deficiency Syndrome (AIDS) pandemic have had a profound effect on the health and social life of people in Nigeria. This study was aimed at assessing the perception level of voluntary counseling/ testing and knowledge/ awareness of HIV/AIDS among the adult population in Ugep town of Cross-River State of Nigeria. One hundred and sixty (160) male and female residents of Ugep metropolis between the ages of 17 and 60 were surveyed. A 20-item structured questionnaire was administered to participants. Analysis of the responses showed that one hundred and twenty four $(77.5 \%)$ understands what HIV/ AIDS is while $98.1 \%$ are aware of the routes of transmission. Sixty five percent and $98.8 \%$ respectively have a good knowledge of the signs/symptoms and prevention of the disease. Only $15.6 \%$ of the respondents are aware of the availability of medical treatment for HIVIAIDS. Sixty seven $(47.5 \%)$ respondents affirmed that they will stigmatize people living with HIVIAIDS. One hundred and forty nine (93.1\%) were aware of Voluntary Testing and Counselling (VCT) of which ninety five (59.4\%) had undergone one. A minority group of the respondents $63(39.4 \%)$ believed that life would still be worth living if they are sero positive. Eighty eight $(61.2 \%)$ said they cannot disclose their HIV status to anyone while sixty five $(40.6 \%)$ believed that VCT can bring about an HIV-free society. Sixty five $(40.6 \%)$ respondents have never gone for VCT for several reasons. Alarmingly, 20 respondents said they would commit suicide if they were to be sero-positive while 5 would spread the virus to others. The level of knowledge and awareness of HIVIAIDS is yet to achieve desired goals and impact. There is need for urgent intervention by the relevant bodies to educate and enlighten the populace.
\end{abstract}

\section{Keywords: Awareness; HIV/AIDS; Voluntary counselling}

\section{Introduction}

The Human Immune deficiency Virus (HIV) and Acquired Immune Deficiency Syndrome (AIDS) pandemic have had a profound effect on the health and social life of people in sub Saharan Africa, especially in Nigeria, which has the third-largest number of people living with HIV in the world [1]. Infection levels vary radically across this large country from $1.3 \%$ in the southwest to $4.9 \%$ in northern and central areas [1]. Frightening figures of its prevalence serve as a constant reminder of the demographic, humanitarian, economic and developmental crisis posed by the HIV/AIDS scourge [2]. Since the first reported case of AIDS in Nigeria in 1986, the prevalence of the infection continued to rise from $1.8 \%$ in 1991 to $4.5 \%$ in 1996 , reached a peak of $5.8 \%$ in 2001 , reduced to $5.0 \%$ in $2005,4.4 \%$ in 2006 and $3.8 \%$ in 2008 [3]. The National Intelligence Council reported that Nigeria along with four other highly populated countries in the world, is anticipated to fuel the continued pandemic of HIV/AIDS and the adult prevalence was projected to be $10-15$ million (18-26\%) by 2010 [4]. However Nigerian National Action Committee on AIDS (NACA) had projected a prevalence of $6-10 \%$ in adult population by 2010 and for this reason HIV/AIDS is now regarded as a potent national public health threat that threatens to wreak havoc on the nation's delicate demographic balance [3]. CrossRiver is one of the states in Nigeria known for tourism. It is a costal state in Eastern Nigeria, located in Niger Delta. It occupies 20,156 kilometres and shares boundaries with Benue state in the North, Enugue and Abia States in the West, to the East by Cameroon Republic and to the south by Akwa-Ibom and the Atlantic Ocean Traditional festivals to farming activities are observed in local government areas of Cross River State such as Yarkurr in which Ugep is the local government headquarters [5]. These festivals are observed annually to celebrate the rich harvest of the season. Ugep, noted for the popular annual New Yam Festival 'Leboku', is one of the sub-urban communities that make up Cross-River State [6]. During the Leboku festival, people keep away from intense farming activities and exchange visits with their families. Tourism activities greatly increase in Ugep within this period with notable movement of people into the community [7]. In view of the influx of visitors in this sub-urban community over the years, it is the aim of this work to assess the perception level of voluntary counselling/ testing and knowledge/ awareness of HIV/AIDS among the adult population in Ugep town of Cross-River State of Nigeria.

\section{Materials and Methods}

The study area is Ugep town. Ugep is located in the West-central comer of Cross-River State of Nigeria, about 140 kilometres northwest of Calabar the State capital. Ugep is the headquarters of Yarkurr Local Government Area of Cross-River State and attracts steady stream of immigrants with notable ethnic groups such as Igbo, Ibibio and Hausa who contributes to the diversification of its local economy. Farming is the most predominant economic activity of its inhabitants. Conservative estimates place the Ugep population at 300,000 [8]. Permission

${ }^{*}$ Corresponding author: Akpotuzor Josephine O, Department of Medical Laboratory Science, University of Calabar, Calabar, Nigeria, Tel: +2348037134757; E-mail: josephineakpotuzor@yahoo.com

Received July 19, 2013; Accepted August 22, 2013; Published August 28, 2013

Citation: Akpotuzor Josephine O, Akpan Patience A, Akwiwu Euphoria C (2013) Perception Level of Voluntary Counselling/Testing and Knowledge/Awareness of HIVIAIDS among Adult Population in Ugep Town of Cross-River State of Nigeria. J AIDS Clin Res 4: 234. doi:10.4172/2155-6113.1000234

Copyright: () 2013 Akpotuzor Josephine O, et al. This is an open-access article distributed under the terms of the Creative Commons Attribution License, which permits unrestricted use, distribution, and reproduction in any medium, provided the original author and source are credited. 
Citation: Akpotuzor Josephine O, Akpan Patience A, Akwiwu Euphoria C (2013) Perception Level of Voluntary Counselling/Testing and Knowledge/ Awareness of HIVIAIDS among Adult Population in Ugep Town of Cross-River State of Nigeria. J AIDS Clin Res 4: 234. doi:10.4172/21556113.1000234

Page 2 of 3

to conduct this survey was given by the Department of Medical Laboratory Science ethical committee, University of Calabar before commencement of the study. The Paramount Ruler and the individual persons that participated in the study also gave consent. The participants were informed of the nature, scope and purpose of the study and only those who voluntarily agreed participated. A total of 160 residents of Ugep metropolis both males and females were included in the study. The participants through systemic method with random start were selected for the survey, which included civil servants, farmers, business owners and students. A 20-item questionnaire was administered to participants after they have been mobilized to gather in a particular place between 10.00 am and 12 noon on the days of visit. The questions were structured and aimed at assessing the knowledge and awareness of participants on the subject of HIV/AIDS and Voluntary Counselling and Testing (VCT). Questionnaires were administered and retrieved by the researchers after a thirty-minute interval. The sample size was based on $12 \%$ prevalence rate of HIV in Cross-River state of Nigeria report by This Day 2005 and sample size formulae of $N=Z^{2 \times} P(1-P) / E^{2}$ (where $Z$ score is $1.96, \mathrm{P}$ is $12 \%$ prevalence recorded for Cross-River State and $\mathrm{E}$ is 0.05 error limit) [9].

\section{Results}

A total of 160 subjects participated as respondents in this survey and their demographic distribution is shown in table1. In the present study, over $70 \%$ of the respondents understand what HIV/AIDS is and very high level of awareness of the routes of transmission (Table 1). A good knowledge of the signs/symptoms and prevention of the disease was also observed (Table 1). Fewer respondents are aware of the availability of medical treatment for HIV/AIDS, while greater percentage claims they have no idea. Over $40 \%$ affirmed that they will stigmatize people living with HIV/AIDS (Table1). Above $90 \%$ of the respondents who were aware of Voluntary Testing and Counselling (VCT) got their

\begin{tabular}{|l|c|c|c|}
\hline & & $\begin{array}{c}\text { Number of respondents } \\
(\mathrm{N}=160)\end{array}$ & Percentage (\%) \\
\hline \multirow{4}{*}{ Gender } & Male & 90 & 56.3 \\
& Female & 70 & 43.7 \\
Occupation & Civil servants & 50 & 31.3 \\
& Farmers & 17 & 10.6 \\
& Traders & 69 & 43.1 \\
\multirow{5}{*}{ Age range (years) } & Students & 24 & 15.0 \\
& $11-20$ & 20 & 12.5 \\
& $21-30$ & 53 & 33.1 \\
& $31-40$ & 42 & 26.3 \\
& $41-50$ & 32 & 20.0 \\
\hline
\end{tabular}

Table 1: Demographic Distribution of Respondents.

\begin{tabular}{|l|l|l|l|}
\hline S/N & QUESTION & YES (\%) & NO (\%) \\
\hline 1 & What is HIVIAIDS? & $124(77.5)$ & $36(22.5)$ \\
2 & How is it contracted? & $157(98.1)$ & $3(1.9)$ \\
3 & Knowledge of signs and symptoms & $104(65)$ & $56(35)$ \\
4 & Knowledge of prevention & $158(98.8)$ & $2(1.2)$ \\
5 & Knowledge of treatment & $25(15.6)$ & $135(84.4)$ \\
6 & Do you stigmatize people with HIVIAIDS? & $76(47.5)$ & $84(52.5)$ \\
7 & Are you aware of VCT & $149(93.1)$ & $11(6.9)$ \\
8 & Medium of awareness a) Radio & $112(75.2)$ & $40(25)$ \\
& Have you ever gone for VCT & $37(24.8)$ & $120(75)$ \\
9 & If you are sero positive, do you think life is worth & $95(59.4)$ & $65(40.6)$ \\
10 & living & $63(39.4)$ & $97(60.6)$ \\
11 & Can you disclose your status after a positive & $62(38.8)$ & $98(61.2)$ \\
12 & VCT to anyone else & $65(40.6)$ & $95(59.4)$ \\
\hline
\end{tabular}

Table 2: Knowledge and Awareness of HIVIAIDS

\begin{tabular}{|l|c|c|}
\hline REASONS & NUMBER OF SUBJECTS & PERCENTAGE (\%) \\
\hline Not aware & 11 & 16.9 \\
No money & 10 & 15.4 \\
Disability & 1 & 1.5 \\
Lack of trust of the result & 1 & 1.5 \\
Afraid & 4 & 6.2 \\
No need & 16 & 24.6 \\
Busy schedules & 22 & 33.9 \\
EXPECTED ACTION IF VCT IS & 20 & 12.5 \\
POSITIVE & 94 & 58.8 \\
Suicide & 19 & 11.9 \\
Do nothing but pray & 22 & 13.7 \\
Go for ARV drugs & 5 & 3.1 \\
Self denial & & \\
Spread to others & & \\
\hline
\end{tabular}

Table 3: Reasons For Not Going For VCT.

information from radio and television programmes with majority calming radio (Table 2). More than a half of the respondents had undergone VCT and only less than $40 \%$ of them believed that life would still be worth living if they are tested sero- positive as well as a free HIV society if VCT is maintained (Table 1). On disclosure of status after VCT, 88 persons said they couldn't disclose their status to anyone. Sixty five respondents claimed they have never gone for VCT with majority attributing it to busy schedules (Table 3 ). When asked what they would do if they were to be sero-positive, over $50 \%$ claimed to pray and wish it away while negligible number said they will go for Anti Retroviral (ARV) treatment whereas others gave various reasons as shown in Table 3.

\section{Discussion}

The findings of this study have shown that the study population had a good knowledge of what HIV/AIDS is and its routes of transmission. This is comparable to previous findings obtained among teachers in Ogun state, western Nigeria and from adolescents in Katsina state, northern Nigeria respectively ( $83.3 \%$ and $91.2 \%$, and $96 \%$ and $88.6 \%$ ) $[10,11]$. A high level of awareness on the prevention of HIV was recorded in the present study and this was similar to values obtained previously in the western and northern Nigeria respectively $[10,11]$ thus suggesting that the enlightenment campaign on prevention of HIV was well perceived by the populace.

A 52.5\% awareness level of availability of anti retroviral treatment among the population in the Northern, Nigeria as reported by Ruma [11] is a far cry from that obtained in this present study (Table 1) and that recorded in western Nigeria $16.3 \%[10,11]$. The implication of this is that a lot number of subjects who may be infected and affected may still leave in denial and may not come out to receive treatment hence may constitute a huge risk in terms of spreading the virus to others. We therefore suggest huge enlightenment campaign toward this direction by the Nigerian National Action Committee on AIDS (NACA) as well as State Action Committee on AIDS (SACA) to these areas with low perception levels. Again over $40 \%$ of our study population believed they should stay away from persons infected and affected by HIV. This figure is higher than that obtained in the northern part of the country (15\%) and $(8.9 \%)$ in the west. This finding points to high level of stigmatisation in the study area (Ugep) and therefore more enlightenment campaign in this direction. There is high perception of voluntary counselling and testing among our study population. Over $70 \%$ of the study group claimed that their medium of awareness was mostly through radio hence this medium should be maximally utilized in the dissemination of information by concern organizations and agencies involved in HIV/AID and other infectious disease programmes in this locality and Nigeria in general because of its wider coverage. 
Citation: Akpotuzor Josephine O, Akpan Patience A, Akwiwu Euphoria C (2013) Perception Level of Voluntary Counselling/Testing and Knowledge/ Awareness of HIVIAIDS among Adult Population in Ugep Town of Cross-River State of Nigeria. J AIDS Clin Res 4: 234. doi:10.4172/21556113.1000234

Page 3 of 3

A little above half of the study group had made themselves available for VCT (Table 1) while others that have not gone gave various reasons as shown in Table 3. The major issue here is fear, fear to be told they have the virus, fear of what will happen to them after knowing the status, fear of stigmatization and fear of accessing the drugs etc, which we think may have amounted to their inability to go for VCT. With these fears, it does appear that over $1 / 3$ of our study population appears to be in denial of the reality and magnitude of impact of HIV/ AIDS disease (Table 3). Again, over $50 \%$ of the study population when asked what they would do if tested sero-positive claimed they would not go for medication but would rather resign to faith and wish it away while some persons though negligible in number declared to spread the virus to others. This perception is a far cry from the right steps in reducing/preventing spread. These findings call for greater concern in the fight to reduce the scourge of HIV/AID disease. There is need for urgent intervention by the relevant bodies to educate and enlighten the populace on these various issues raised in order to keep them better informed about HIV/AIDS disease. In conclusion we say that the perception level of knowledge and awareness of HIV/AIDS disease though high in our study population is yet to achieve the desired impact in terms of response to stigmatization, embracing anti retroviral treatment, a commitment to reduce spread of infection as well as the desired mental liberation of infected/affected persons as reflected by the $12.5 \%$ of the study population who claimed they will commit suicide if tested sero-positive.

\section{References}

1. Joint United Nation Program on HIVIAID, Fact Sheet 06.

2. Ogunbodede EO (2004) HIVIAIDS situation in Africa. Int Dent J 54: 352-360.

3. Federal Ministry of Health of Nigeria (2003) National HIVIAIDS and reproductive Health Survey. A technical report from Federal Ministry of Health, Nigeria.

4. National Intelligence Council (2002) The next wave of HIV/AIDS Nigeria, Ethiopia, Russia, India and China. Gordon DF (Ed.), Washington, DC.

5. Cross River State

6. The Tide Online (2008) CRS Celebrates New yam festival.

7. Oladoyin, Dolapo (2008) Cross River State's Tourism Drive through the Leboku Festival. Tourism ROI.

8. Obono O (2001) Matriclan Priests and populationPolicy in Nigeria. Population and Development Review 92: 103-111

9. This Day All Africa Global Media.

10. Bankole OM, Mabekoje OO (2008) Awareness and opinions about HIVIAIDS among secondary school teachers in Ogun State, Nigeria. Scientific Research and Essay 3: 245-253.

11. Ruma MM (2009) Knowledge and awareness of HIVIAIDS among some senior secondary school students in Katsina, Nigeria. Bayero Journal of Pure and Applied Sciences 2: 121-126. 